\title{
Efficacy of Aeromonas hydrophila formalin-killed cells and lipopolysaccharides vaccines in maternal immunity of tilapia broodstock and the offspring resistance
}

\section{Efikasi vaksin formalin killed cells dan lipopolisakarida Aeromonas hydrophila pada imunitas maternal induk ikan nila dan ketahanan benih yang dihasilkannya}

\author{
Rahma Mulyani', Sukenda ${ }^{2}$, Sri Nuryati ${ }^{2}$ \\ ${ }^{1}$ Graduate School of IPB University, Study Program of Aquaculture Science \\ ${ }^{2}$ Department of Aquaculture, Faculty of Fisheries and Marine Sciences, IPB University, Bogor, West Java, \\ Indonesia 16680 \\ *Corresponding author: sukenda@ipb.ac.id
}

(Received January 4, 2018; Accepted May 12, 2019)

\begin{abstract}
The study aimed to analyze the efficacy of Aeromonas hydrophila formalin-killed cells (FKC) and lipopolysaccharides (LPS) vaccines in maternal immunity of tilapia broodstock and the resistance of the offsprings. This study consisted of two consecutive studies. Firstly, the broodstocks were vaccinated with PBS (non-vaccinated), FKC, LPS, and combinations of FKC and LPS. Secondly, the offsprings from both the vaccinated and non-vaccinated broodstock were vaccinated with the same vaccine for broodstock by immersion method. After vaccination, the offsprings were challenged with pathogenic $A$. hydrophila. Antibody level and lysozyme were measured in the broodstock, egg, and offsprings. In the first experiment, the result showed that vaccinated broodstock and their offsprings had delivered a significant antibody level and lysozyme activity compared with the control. The highest relative percent survival (RPS) of offspring resulted from the combination of FKC and LPS vaccinated broodstock at 5, 10, and 15 days post-hatching at $85.00 \%, 75.23 \%$, and $67.56 \%$, respectively. The second experiment showed vaccinated offsprings produced from vaccinated broodstock had a higher RPS than the RPS of vaccinated offsprings which produced from non-vaccinated broodstock. In conclusion, vaccination that using a combination of FKC and LPS vaccine in broodstock potentially improved the maternal immunity and protect their offspring from A. hydrophila infection.
\end{abstract}

Keywords: Aeromonas hydrophila, antibody, maternal immunity, tilapia, vaccination

\begin{abstract}
ABSTRAK
Penelitian ini bertujuan menganalisis efikasi vaksin formalin-killed cells (FKC) dan lipopolisakarida (LPS) A. hydrophila pada imunitas maternal induk ikan nila dan ketahanan benih yang dihasilkan. Dalam penelitian ini, terdapat dua penelitian. Pertama, induk ikan nila divaksin dengan PBS (non-vaksinasi), vaksin FKC, LPS, dan kombinasi vaksin FKC dan LPS. Benih selanjutnya diuji ditantang dengan menggunakan patogen A. hydrophila pada 5,10 , dan 15 hari pasca menetas. Kedua, benih yang dihasilkan oleh induk yang telah divaksinasi dan induk yang tidak divaksinasi tersebut divaksin dengan vaksin yang sama seperti pada induk dengan metode imersi. Setelah vaksinasi, keturunan diuji tantang dengan patogen A. hydrophila. Tingkat antibodi dan lisozim diukur pada induk, telur, dan benih. Pada percobaan pertama, hasilnya menunjukkan bahwa induk yang divaksinasi dan benih menunjukkan tingkat antibodi dan aktivitas lisozim yang signifikan dibandingkan dengan kontrol. Persentase kelangsungan hidup relatif (RPS) tertinggi benih yang dihasilkan dari induk yang divaksinasi FKC dan LPS masing-masing pada 5,10, dan 15 hari pascatetas pada 85,00\%; 75,23\%; dan 67,56\%. Percobaan kedua menunjukkan bahwa benih yang divaksinasi dari induk yang divaksin menunjukkan RPS yang lebih baik daripada benih yang divaksinasi dari induk yang tidak divaksin. Vaksinasi menggunakan kombinasi FKC dan LPS pada induk berpotensi meningkatkan kekebalan induk dan melindungi benih dari infeksi A. hydrophila.
\end{abstract}




\section{INTRODUCTION}

Motile aeromonad septicemia (MAS) is a bacterial disease caused by Aeromonas hydrophila bacteria that is capable of attacking fish from fingerling to broodstock phase. This disease generally affects many freshwater fish species in tropical waters, one of which is tilapia Oreochromis niloticus (Rahmaningsih, 2012; Li et al., 2017). According to Dehghani et al. (2012), A. hydrophila bacteria live in freshwater as normal flora. A. hydrophila bacterium is capable of causing tissue swelling, stomach oedema, reddish body, necrosis, ulceration, and haemorrhagic septicemia in fish (Citarasu et al., 2011; Hardi \& Pebrianto, 2012; Fu et al., 2014).

The development of disease management in fish culture nowadays tends to use preventive principle, such as vaccines. Vaccines can induce specific and nonspecific immunity of fish, besides protecting fish from certain pathogens in the long term period. Vaccination combined with good cultural management system practices can prevent disease attacks (Barman et al., 2013; Sugiani et al., 2013; Aaby et al., 2014; Amrullah et al., 2014). Fingerling quality stocked becomes one aspect that affects the success of tilapia culture (Nisaa et al., 2016). Vaccination given to larvae in preventing disease has not given maximum results due to body defense limitation system. Larvae have not been able to respond to the vaccine. Larvae have to withstand direct exposure to pathogenic bacteria in aquatic environments until the adaptive immune system is formed (Swain \& Nayak, 2009; Zhang et al., 2013). Therefore, building immunity through maternal immune transfer in fish should be done to provide larval protection against pathogenic attacks as early as possible (Mingming et al., 2014; Zhang et al., 2014). Maternal immunity transfer can establish broodstock specific and non-specific immunity as well as providing protection to the offspring produced against $A$. hydrophila bacterial infection (Sukenda et al., 2017).

Some types of vaccine candidates from A. hydrophila intact bacterial cell supplies, such as formalin-killed cell (FKC) and lipopolysaccharides (LPS) have been used to prevent A. hydrophila (Dehghani etal., 2012). FKC is a vaccine from $A$. hydrophila bacterial intact cell containing bacteria and proteins by bacterial inactivation using BNF 3\%. The results reported that FKC vaccine applied to tilapia broodstock gave RPS value $78.26 \%$ on day five to the offspring after challenged with $A$. hydrophila (Sukenda et al., 2017), while lipopolysaccharides were a molecular constituent of Gram-negative bacterial outer membranes that are toxic to fish, making the bacteria become virulent. This molecule is amphiphilic and composed of oligosaccharides, polysaccharides, $\mathrm{O}-$ antigen, and lipid-A in the form of acetylglucosamine phosphate fatty acid (Merino et al., 2015). LPS in bacteria are able to provide an immunomodulatory effect on the host (Dehghani et al., 2012).

The general purpose of this study was to determine effective vaccine substance between LPS, FKC, and combined LPS and FKC vaccine from $A$. hydrophila for motile aeromonas septicemia (MAS) prevention on tilapia fingerling. The specific purposes were to testify the main immunogenicity of vaccinated broodstock and offspring produced, fingerling protection and immunogenicity condition from vaccinated broodstock, and fingerling protection from vaccinated and unvaccinated broodstock.

\section{METHODS}

\section{Research design}

The study design consisted of two consecutive studies. The first study was female broodstock vaccination and the second study was offspring vaccination on day 20 of rearing from broodstock spawning on the first study.

\section{Research procedures}

Vaccine supply test

A vaccine tested in this study was formalinkilled cells (FKC) and lipopolysaccharides (LPS) vaccine supply from $A$. hydrophila bacteria. FKC vaccine or whole-cell vaccine was created by $A$. hydrophila inactivation using buffered neutral formalin (BNF) 3\%. The generated whole-cell vaccine of $A$. hydrophila referred to Sugiani et al. (2013). A . hydrophila bacteria was cultured in trypticase soy broth (TSB) medium and incubated with shaker for 24 hours at $28^{\circ} \mathrm{C}$. Total of bacteria in the culture medium was calculated using total plate count (TPC) method. The result of bacterial culture $\left(10^{9} \mathrm{CFU} / \mathrm{mL}\right)$ was inactivated by adding BNF $3 \%$ of culture medium volume and incubated for 24 hours at $28^{\circ} \mathrm{C}$. Inactivated bacterial cell was harvested by centrifugation method with 
$5000 \mathrm{rpm}$ for 30 minutes. Supernatant created was subsequently taken and washed twice using sterile phosphate-buffered saline (PBS). Washed supernatant was resuspended to the initial volume using sterile PBS.

After vaccine produced, viability test was done by streaking the vaccine candidate into TSA medium. Vaccine candidate that showed no growth was safe to be used. LPS vaccine was made based on Fernandez et al. (2014). A. hydrophila isolate was cultured in TSB media as much as $50 \mathrm{~mL}$ and incubated for 24 hours at $28^{\circ} \mathrm{C}$. The result of bacterial culture $\left(10^{9} \mathrm{CFU} / \mathrm{mL}\right)$ was centrifuged at $1600 \mathrm{rpm}$ for 20 minutes and injected with PBS ten times of product volume generated. Bacterial cells were heated for two hours at $100^{\circ} \mathrm{C}$. Bacterial cells were centrifuged and discarded the supernatant. Bacterial cells were suspended in ethyl alcohol $95 \%$ ten times of cell liquidity and incubated at $37^{\circ} \mathrm{C}$ for 4 hours. Bacterial cells were washed with acetone and resuspended to the initial volume with PBS. After the vaccine production is completed, the viability test was done by streaking the vaccine candidate solution to trypticase soy agar (TSA). Vaccine candidate that showed no growth was safe to be used.

\section{First study}

Tilapia broodstock vaccination and spawning

Female tilapia nirwana strain weighing 197 $\pm 14.9 \mathrm{~g}$ vaccination was done after one week of ovulation period or at gonad maturation level two (TKG2) (Nisaa et al., 2016). The vaccine was injected intraperitoneally with $10^{9} \mathrm{CFU} /$ $\mathrm{mL}$ concentration at $0.4 \mathrm{~mL} / \mathrm{kg}$ fish doze. Treatments applied were the injection of PBS (control), FKC vaccine, LPS vaccine, and 50:50 (V/V) combination of FKC and LPS (GAB). Natural spawning ratio between male and female broodstock was $1: 3$ conducted in a concrete tank with $2.5 \times 2.5 \times 1 \mathrm{~m}^{3}$ size.

\section{Tilapia offspring challenge test}

Tilapia offspring challenge test was done by soaking the offspring into the solution containing A. hydrophila at the age of 5,10, and 15 days after hatching with $10^{7} \mathrm{CFU} / \mathrm{mL}$ concentration for 30 minutes. The percentage of mortality and relative percent survival (RPS) on each treatment with three times replication were calculated on the seventh day after vaccination.
Serum preparation sample from broodstock, egg liquid, and offspring body

Serum samples in this study were obtained by taking blood from the broodstock through the tailend veins. Serum was collected by centrifuged $5000 \mathrm{rpm}$ for 10 minutes at $4^{\circ} \mathrm{C}$. Serum was separated into the microtube and stored at $-20^{\circ} \mathrm{C}$ for antibody and lysozyme test. Eggs were taken after broodstock spawning, while the offspring samples were taken on $5,10,15$, and 20 days after hatching. Ten eggs and five offsprings were homogenized each in PBS-T (PBS $+0.05 \%$ Tween-20) solution with 1:4 (g/v) ratio. Egg and offspring sample was centrifuged in $5000 \mathrm{rpm}$ for 10 minutes at $4^{\circ} \mathrm{C}$. The supernatant was separated into microtube and stored at $-20^{\circ} \mathrm{C}$ for antibody and lysozyme level test.

\section{Second research}

\section{Fingerling vaccination}

Second stage vaccination from the first study on fingerling aged 20 days after hatching with $\mathrm{K}+$ (unvaccinated fingerling from unvaccinated broodstock), $\mathrm{K}+\mathrm{FKC}$ (unvaccinated fingerling from FKC vaccinated broodstock), K+LPS (unvaccinated fingerling from LPS vaccinated broodstock), $\mathrm{K}+\mathrm{GAB}$ (unvaccinated fingerling from $\mathrm{GAB}$ vaccinated broodstock), FKC (FKC vaccinated fingerling from $\mathrm{FKC}$ vaccinated broodstock), LPS (LPS vaccinated fingerling from LPS vaccinated broodstock), and GAB (GAB vaccinated fingerling from GAB vaccinated broodstock). Fingerling weighing $0.16 \pm 0.021 \mathrm{~g}$ was soaked in vaccine solution with $10^{7} \mathrm{CFU} / \mathrm{mL}$ for 30 minutes as much as 20 fingerlings on each treatment replicated three times.

\section{Tilapia fingerling challenge test}

Tilapia fingerling reared for 11 days after vaccination was challenged with $A$. hydrophyla $\left(10^{7} \mathrm{CFU} / \mathrm{mL}\right)$ by soaking the fingerlings into the media containing a bacterial solution for 30 minutes. Soaked fingerlings were reared in an aquarium sized $30 \times 20 \times 20 \mathrm{~cm}^{3}$ with 20 fingerlings in each aquarium. The percentage of mortality and relative percent survival (RPS) on fingerlings were calculated on 7 days after the challenge test.

\section{Fingerling body liquid preparation}

Fingerling body liquid was obtained from fingerlings in each treatment collected on 11 days after vaccination. Five fingerlings were 
homogenized in PBS-T (PBS $+0.05 \%$ Tween-20) solution at $1: 4(\mathrm{~g} / \mathrm{v})$ ratio. Fingerling samples obtained were centrifuged in $5000 \mathrm{rpm}$ for 10 minutes at $4^{\circ} \mathrm{C}$. The supernatant was separated into a microtube and stored at $-20^{\circ} \mathrm{C}$ for antibody and lysozyme level test.

\section{Parameter}

Relative percent survival (RPS)

Relative percent survival (RPS) was calculated using the following formula:

Fingerling mortality rate

$$
\text { RPS }(\%)=\frac{\text { Mortality of vaccinated fish }}{\text { Mortality of control fish }} \times 100
$$

Fingerling mortality rate was calculated after challenged with A. hydrophila using the following formula:

Antibody

$$
\text { Mortality }(\%)=\frac{\text { Total dead fish }}{\text { Total population }} \times 100
$$

Broodstock, egg, and fingerling antibody level were measured using indirect enzyme-linked immunosorbent assay (ELISA) method (Sumiati et al., 2015). Antigen concentration was measured using Bradford spectrophotometry method. A total of $100 \mu \mathrm{L}$ antigen that has been diluted 1:1 using PBS ( $\mathrm{pH}$ 7.2) was inserted in microplates well added with $100 \mu \mathrm{L}$ carbonate-bicarbonate buffer ( $\mathrm{pH}$ 9.6) on each well. Antigen was incubated at $4^{\circ} \mathrm{C}$ for 12 hours. Well was washed using PBS-T (PBS pH $7.4+0.05 \%$ Tween-20) and added with $100 \mu \mathrm{L}$ bovine serum albumin (BSA, Sigma) $3 \%$ (w/v) in $\mathrm{H}_{2} \mathrm{O}$, then incubated at $25^{\circ} \mathrm{C}$. The mixture was incubated for an hour and washed using PBS-T solution.

Broodstock blood serum was diluted in PBS-T (pH 7.2) 1:50 (v/v) solution, while egg and body liquid were diluted in PBS-T ( $\mathrm{pH}$ 7.2) solution $1: 16$, then inserted into the microplates as much as $100 \mu \mathrm{L}$ with three replications and incubated for an hour at $25^{\circ} \mathrm{C}$, then washed using PBS-T. Long-chain anti-tilapia immunoglobulin for polyclonal specific antibody was diluted in PBS-T solution 1:200 and added as much as $100 \mu \mathrm{L}$ to each microplate, then incubated for an hour at $25^{\circ} \mathrm{C}$ and washed using PBS-T solution twice. Subsequently, peroxidase-conjugated rabbit antirabbit (Sigma) was diluted in PBS-T to 1:5000 as much as $100 \mu \mathrm{L}$ was added to each microplate well. The microplate was incubated at $25^{\circ} \mathrm{C}$ for an hour and washed. $100 \mu \mathrm{L}$ one step Ultra TMB-
ELISA (Sigma) (TMB $5 \mathrm{mg}+10 \mathrm{\mu l} \mathrm{H}_{2} \mathrm{O}_{2} 38 \%$ in 5 $\mathrm{mL}$ buffer acetate $\mathrm{pH} 5$ ), while blanko was added $50 \mu \mathrm{L} \mathrm{H}_{2} \mathrm{SO}_{4} 3 \mathrm{M}$ into the first well of microplate and incubated for 20 minutes at $25^{\circ} \mathrm{C}$. ELISA reaction was stopped by adding $50 \mu \mathrm{L} \mathrm{H}_{2} \mathrm{SO}_{4} 3 \mathrm{M}$ into the well. Optical density (OD) of microplate was read using microplate reader (Kayto RT2100C) on $450 \mathrm{~nm}$ absorbance. Antibody level was expressed in $\mathrm{OD}$ value.

\section{Lysozyme activity}

Lysozyme level on broodstock, egg, and fingerling was determined using the method of Hanif et al. (2005). Egg and fingerling body liquid as much as $100 \mu \mathrm{l}$ were added with the liquid suspension of Micrococcus lysodeikticus (Sigma) as much as $100 \mu \mathrm{l}(0.4 \mathrm{mg} / \mathrm{mL}$ in PBS $\mathrm{pH}$ 6.2) at $25^{\circ} \mathrm{C}$. Lysozyme level was read using microplate reader (Kayto RT-2100C) with 450 $\mathrm{nm}$ absorbance for 30 seconds and 30 minutes mixing. The lysozyme activity unit was measured by decreased OD value of 0.001 per minute. Lysozyme activity was formulated below:

Lysozyme activity $($ unit $/ \mathrm{mL})=\frac{\text { (initial OD-final OD }) \times 1000}{\text { final time measurement }}$

\section{Data analysis}

This study used a completely randomized design method. Data obtained was collected using Microsoft Office Excel 2010 and analyzed using one way ANOVA method with SPSS 16.0 software application.

\section{RESULT AND DISCUSSION}

\section{Result}

First study

Mortality rate and relative percent survival (RPS) value on tilapia offspring

The mortality rate of offspring in GAB vaccinated broodstock treatment was lower than the control treatment and LPS on the fifteenth day, but offspring from GAB treatment did not differ significantly $(\mathrm{P}>0.05)$ with $\mathrm{FKC}$ treatment on the fifteenth day. RPS value of GAB and FKC treatment on offspring also showed no significant difference $(\mathrm{P}>0.05)$, but showing a significant difference to the control treatment on the fifteenth day. Mortality rate and RPS value are presented in Table 1. 
Table 1. Mortality rate and RPS value on offspring 5, 10, 15 days after hatching

\begin{tabular}{cccc}
\hline Offspring age (day after hatching) & Treatment & Mortality $(\%)$ & RPS (\%) \\
\hline 5 & Control & $70.00 \pm 5.00^{\mathrm{c}}$ & - \\
& FKC & $15.00 \pm 2.8^{8 \mathrm{a} b}$ & $77.77 \pm 5.87^{\mathrm{ab}}$ \\
& LPS & $25.00 \pm 5.00^{\mathrm{b}}$ & $65.00 \pm 5.00^{\mathrm{a}}$ \\
& GAB & $10.00 \pm 2.88^{\mathrm{a}}$ & $85.00 \pm 5.35^{\mathrm{b}}$ \\
& Control & $73.33 \pm 1.66^{\mathrm{c}}$ & - \\
& FKC & $20.00 \pm 5.77^{\mathrm{a}}$ & $72.69 \pm 7.72^{\mathrm{b}}$ \\
& LPS & $36.66 \pm 1.66^{\mathrm{b}}$ & $50.00 \pm 1.92^{\mathrm{a}}$ \\
& GAB & $18.33 \pm 6.00^{\mathrm{a}}$ & $75.23 \pm 7.79^{\mathrm{b}}$ \\
& Control & $76.66 \pm 3.33^{\mathrm{c}}$ & - \\
& FKC & $26.00 \pm 3.33^{\mathrm{a}}$ & $65.47 \pm 4.39^{\mathrm{b}}$ \\
& LPS & $41.66 \pm 4.40^{\mathrm{b}}$ & $45.83 \pm 4.16^{\mathrm{a}}$ \\
& GAB & $25.00 \pm 2.88^{\mathrm{a}}$ & $67.56 \pm 2.64^{\mathrm{b}}$ \\
\hline
\end{tabular}

Note: Different superscript letter on the same column shows significant different treatment (Duncan test; $\mathrm{P}<0.05$ ). $\mathrm{K}+$ (unvaccinated fingerling from unvaccinated broodstock), $\mathrm{K}+\mathrm{FKC}$ (unvaccinated fingerling from FKC vaccinated broodstock), K+LPS (unvaccinated fingerling from LPS vaccinated broodstock), K+GAB (unvaccinated fingerling from GAB vaccinated broodstock), FKC (FKC vaccinated fingerling from FKC vaccinated broodstock), LPS (LPS vaccinated fingerling from LPS vaccinated broodstock), and GAB (GAB vaccinated fingerling from GAB vaccinated broodstock).

Table 2. Mortality rate and RPS value of fingerling after vaccination

\begin{tabular}{ccc}
\hline Treatment & Mortality $(\%)$ & RPS $(\%)$ \\
\hline K- & $75.00 \pm 2.88^{\mathrm{c}}$ & - \\
K+FKC & $56.66 \pm 4.40^{\mathrm{b}}$ & $24.50 \pm 4.48^{\mathrm{a}}$ \\
K+LPS & $65.00 \pm 2.88^{\mathrm{cd}}$ & $12.60 \pm 6.84^{\mathrm{a}}$ \\
K+GAB & $55.00 \pm 2.88^{\mathrm{a}}$ & $26.60 \pm 3.39^{\mathrm{a}}$ \\
FKC & $33.33 \pm 6.00^{\mathrm{a}}$ & $56.00 \pm 6.24^{\mathrm{bc}}$ \\
LPS & $43.33 \pm 3.33^{\mathrm{a}}$ & $41.95 \pm 4.92^{\mathrm{b}}$ \\
GAB & $31.66 \pm 1.66^{\mathrm{a}}$ & $57.79 \pm 1.13^{\mathrm{c}}$ \\
\hline
\end{tabular}

Note: Different superscript letter on the same column shows significant different treatment (Duncan test; $\mathrm{P}<0.05$ ). $\mathrm{K}+$ (unvaccinated fingerling from unvaccinated broodstock), $\mathrm{K}+\mathrm{FKC}$ (unvaccinated fingerling from FKC vaccinated broodstock), K+LPS (unvaccinated fingerling from LPS vaccinated broodstock), K+GAB (unvaccinated fingerling from $\mathrm{GAB}$ vaccinated broodstock), FKC (FKC vaccinated fingerling from FKC vaccinated broodstock), LPS (LPS vaccinated fingerling from LPS vaccinated broodstock), and GAB (GAB vaccinated fingerling from GAB vaccinated broodstock).

Antibody and lysozyme level of tilapia egg and broodstock

Antibody level of the egg (A) from FKC (OD: $0.56)$ and GAB (OD: 0.58) vaccinated broodstock treatment were higher than control and LPS treatment. Lysozyme activity of eggs (B) from FKC (76.22 units/ml) and GAB (75.88 units/ $\mathrm{ml}$ ) vaccinated broodstock showed different level from control and LPS, but the lysozyme activity of egg from LPS (39.11 unit/ml) vaccinated broodstock was higher than control treatment (25.51 units/ml). Antibody level formed after broodstock vaccination affected the antibody level of offspring generated from fifth to the fifteenth day. Offspring from treated broodstock showed decreased antibody level from fifth to the twentieth day (Figure 1).

GAB treatment (OD: 0.36-0.52) had the highest antibody level of offspring compared to control (OD: 0.29-0.26) and other treatments on the twentieth day. Lysozyme activity of broodstock vaccinated with GAB (117.77 unit/ $\mathrm{ml})$ and FKC (122.32 unit/ml) was higher than other treatments. Lysozyme activity (B) on control and LPS treatment of broodstock showed no difference. Offspring from treated broodstock 

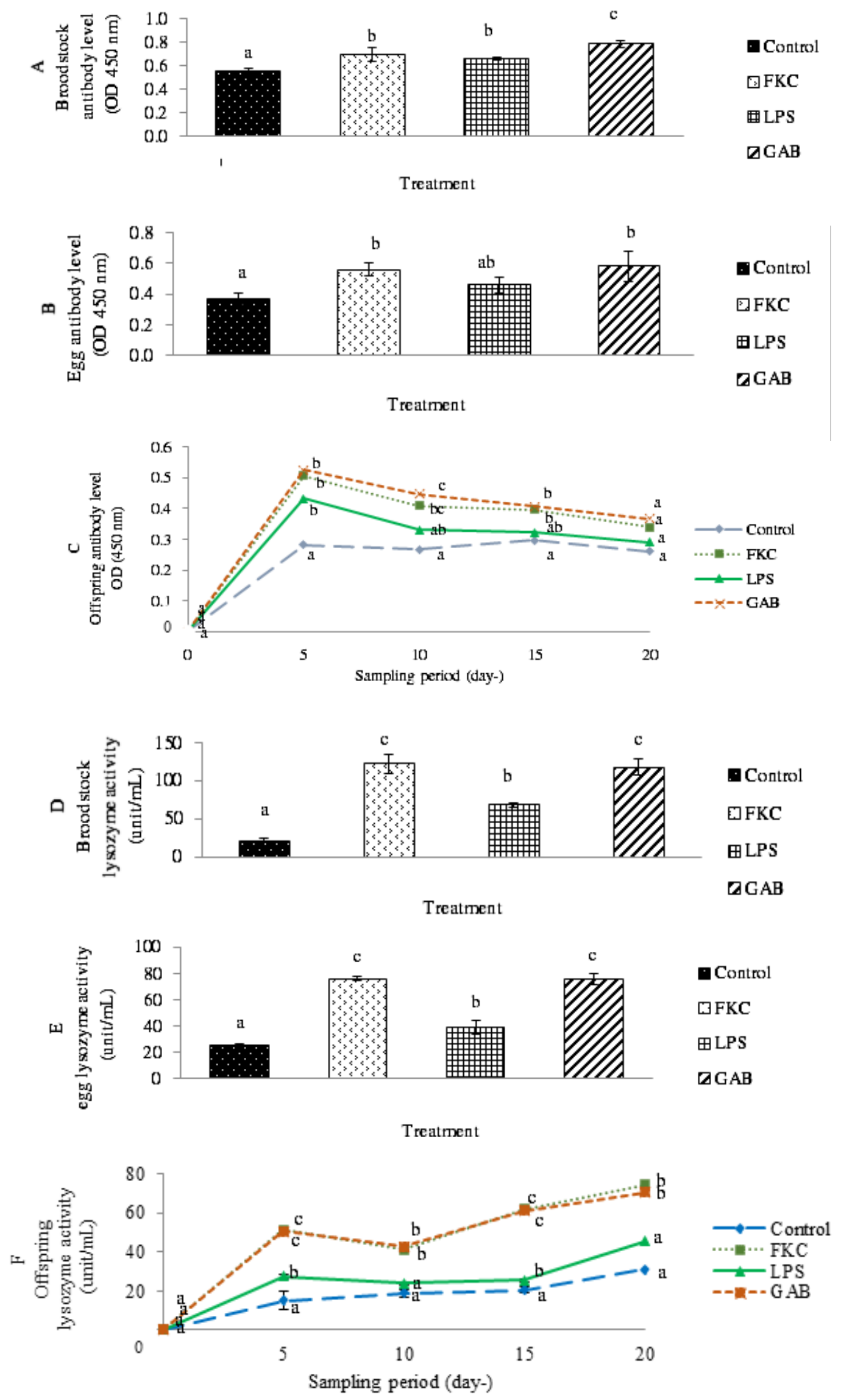

Figure 1. Antibody level of broodstock (A), egg (B), and offspring (C), lysozyme activity of egg (D), broodstock (E), and offspring $(\mathrm{F})$ on each treatment 


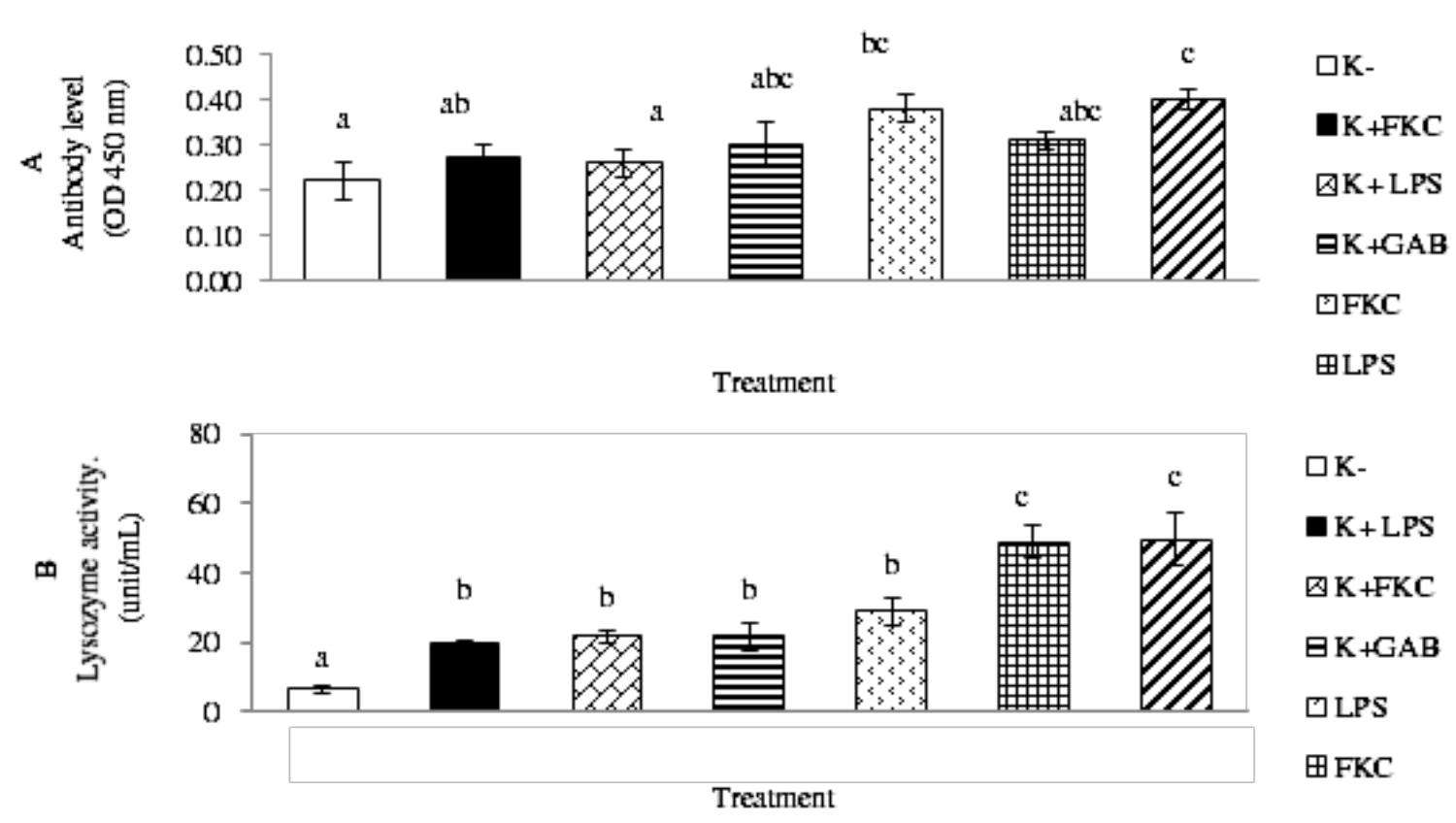

Figure 2. Antibody level (A) and lysozyme activity (B) of fingerling on each treatment. K+ (unvaccinated fingerling from unvaccinated broodstock), $\mathrm{K}+\mathrm{FKC}$ (unvaccinated fingerling from FKC vaccinated broodstock), $\mathrm{K}+\mathrm{LPS}$ (unvaccinated fingerling from LPS vaccinated broodstock), $\mathrm{K}+\mathrm{GAB}$ (unvaccinated fingerling from GAB vaccinated broodstock), FKC (FKC vaccinated fingerling from FKC vaccinated broodstock), LPS (LPS vaccinated fingerling from LPS vaccinated broodstock), and GAB (GAB vaccinated fingerling from GAB vaccinated broodstock).

had decreased antibody level on the fifth to the twentieth day. Lysozyme activity of offspring from GAB treatment (70.22 units/ml) had the highest lysozyme activity compared to other treatments on fifth to twentieth day. Lysozyme activity of offspring from FKC and LPS treatment had significant different value compared to LPS and control (Figure 1).

\section{Second study}

Mortality rate and relative percent survival value of tilapia fingerling after vaccination

Mortality rate of GAB vaccinated fingerling was the lowest value among other treatments. Mortality rate of fingerling on negative control and unvaccinated treatments $(\mathrm{K}+\mathrm{GAB}, \mathrm{K}+\mathrm{FKC}$, and $\mathrm{K}+\mathrm{LPS}$ ) significantly showed the highest value $(\mathrm{P}<0.05)$ (Table 2). RPS value of positive control fingerling on FKC, LPS, and GAB vaccinated broodstock treatment did not significantly differ $(\mathrm{P}>0.05)$, however, differed significantly $(\mathrm{P}<0.05)$ against FKC, LPS, and GAB vaccination on fingerling treatment. LPS and FKC vaccination on fingerling did not show a significant difference, while $G A B$ treatment had a significant difference in RPS value $(\mathrm{P}<0.05)$ with LPS.
Antibody level of fingerling after vaccination

GAB treatment showed a significant difference $\quad(\mathrm{P}<0.05)$ against $\mathrm{K}-, \quad \mathrm{K}+\mathrm{LPS}$, and $\mathrm{K}+\mathrm{FKC}$ treatment. Fingerling on the negative control (unvaccinated fingerling from unvaccinated broodstock), K+LPS, K+FKC, $\mathrm{K}+\mathrm{GAB}$ (unvaccinated fingerling from LPS, FKC, and GAB vaccicated broodstock), and LPS treatment did not show the significantly different result $(\mathrm{P}>0.05)$ (Figure 2). Lysozyme activity of fingerling after vaccination on each treatment differed significantly with $\mathrm{K}-$ treatment. Lysozyme activity after FKC (48.66 units/ml) and GAB (49.66 units/ml) vaccination had no significant difference, but higher than other treatments. Positive control treatment on each vaccination treatment also showed significant difference results $(\mathrm{P}>0.05)$ ranging 19.55-21.77 unit/ml (Figure 2).

\section{Discussion}

Results showed that vaccinations on tilapia broodstock using formalin-killed cells (FKC) and lipopolysaccharides (LPS) vaccine gave a significantly better effect on the maternal immunity transfer from broodstock to offspring. Study on broodstock vaccination was able to 
increase specific and nonspecific immunity, besides decreasing the mortality rate of fish offspring after challenge test (Swain et al., 2006; Mingming et al., 2014; Nisaa et al., 2016; Sukenda et al., 2017). Mortality percentage of offspring on 5,10 , and 15 days after hatching obtained the highest rate at the control treatment, which was significantly different from offspring produced by vaccinated broodstock $(\mathrm{P}<0.05)$. This suggests that the vaccination treatment is able to provide protection as a passive immunity to the offspring better than other treatments, while mortality rate and RPS values of offspring from vaccinated broodstock showed that FKC and GAB treatment was better than the control treatment. This suggests that offspring produced from vaccinated broodstock is able to increase the immunity system, thus making them more resistant to A. hydrophila bacterial infection. In addition, vaccination on the broodstock before spawning gives an advantage to the offspring produced as it was able to suppress the mortality rate after challenged with $A$. hydrophila bacteria compared to offspring from unvaccinated broodstock. The same study result was reported by Sukenda et al. (2017), who stated that $A$. hydrophila wholecell vaccine given to tilapia broodstock was able to suppress mortality rate on the offspring with $78.26 \%$ RPS value on 5 days after hatching. Another study showed that vaccinated offspring using FKC and GAB showed a good value of RPS (Sukenda, 2018). According to Swain and Nayak (2009), sustaining fish broodstock immunity at high level during vitellogenesis and oogenesis processes was important to suppress mortality rate on the larval phase or post-larvae through the maternal immunity transfer. Higher RPS value in GAB treatment than control treatment was also supported by antibody level and lysozyme activity data.

Results on the antibody level of broodstock after vaccination differed significantly compared to the control treatment $(\mathrm{P}<0.05)$. This suggests that vaccination to the broodstock will induce antibody level compared to the unvaccinated broodstock. Antibody level was a parameter for determining the specific immune response formed. Antibody level of vaccinated broodstock will be formed in the body one week after vaccination (Sukenda et al., 2018). The antibody in high concentration could be obtained from fish serum (Magnadottir, 2010). Antibody level in egg and offspring after vaccination were higher than control or unvaccinated treatment. The presence of antibody found in the egg was obtained from the maternal immunity transfer of the vaccinated parent (Nisaa et al., 2016). The presence of antibody in offspring plays an important role in protecting the larvae against environmental and pathogenic influences due to the limited capacity of offspring immune system (Vadstein et al., 2013). The cause of high-level antibodies in egg and offspring vaccination using FKC and GAB was the availability of more antigen in intact cells compared to LPS. In addition to LPS vaccine, $A$. hydrophila cell component is antigenic bacteria that can elicit an immune response as a protein (Lacerda et al., 2015).

Antibody level observed from vaccinated broodstock serum showed higher results compared to unvaccinated broodstock. The same result was reported by Sukenda et al. (2017), who stated that vaccinated broodstock with $A$. hydrophila a wholecell vaccine was able to significantly increase the antibody level. Nisaa et al. (2016) and Pasaribu et al. (2018) also reported that the antibody level of broodstock after vaccination using Streptococcus agalactiae or bivalent vaccine of $S$. agalactiae and A. hydrophila increased compared to control treatment. The antibody was also found in the egg from vaccinated broodstock as allegedly because of the immunoglobulin transfer by broodstock naturally that was metabolized together with the yolk (Zhang et al., 2013).

In the gonad maturation process, environmental signals are received by the central nervous system and transmitted to the hypothalamus. Hypothalamus will release gonadotropinreleasing hormone $(\mathrm{GnRH})$ which works in the pituitary gland. Pituitary releases FSH that works on theca cell and synthesizes testosterone. Granulosic layer that contains aromatase enzyme will convert testosterone into $17 \beta$-estradiol which stimulates the liver to synthesize vitellogenin (prospective yolk). Vitellogenin is carried by the bloodstream and absorbed by the follicle oocytes enlarged to the maximum size for vitellogenesis process. The pathway of this vitellogenesis process has the specific (antibody) and nonspecific (lysozyme) immunity to enter into the yolk to be transferred to the offspring (Swain \& Nayak, 2009; Wang et al., 2011).

Nisaa et al. (2017) reported that tilapia fingerling antibody level originated from vaccinated broodstock decreased slowly until 28 days after hatching. The mechanism of antibody 
formation after vaccination is caused by the contact between the antigen and lymphocytes (B cell and $T$ cell). the antigen in the vaccine can directly induce the proliferation of $\mathrm{B}$ cell into the $\mathrm{B}$ memory cell and plasma cell. B memory cell will store the information about antigen characteristics entering the body, while the plasma cells will produce a specific antibody for antigen. An antigen that enters the body can also be phagocytized by macrophages. After phagocytized, the antigen will be exposed to T-helper cells through major histocompatibility complex (MHC) protein class II. T helper cells are activated by macrophages via cytokine molecules. Activated T-helper cells will produce cytokines that stimulate $\mathrm{B}$ cell, $\mathrm{T}$ memory cells, and cytotoxic $\mathrm{T}$ cells. When the same antigen exposure occurs for the second time, the T memory cell will stimulate B memory cell to proliferate into plasma cells and produce antibody (Reece et al., 2014).

The non-specific immune parameter is the lysozyme activity. Lysozyme activity is one of the bacteriolytic enzymes produced in lysosomes as phagocytes of fish body natural defense response during infection (Akbary et al., 2015; Wang \& Zhang, 2010). Lysozyme activity of broodstock vaccinated with GAB (117.77 units/ml) and FKC (122.32 units $/ \mathrm{ml}$ ) increased significantly and were higher $(\mathrm{P}<0.05)$ than other treatments.

Swain and Nayak (2009) explained that vaccination improves non-specific and specific immune responses. Lysozyme is usually found in serum, homogenic seed, and mucous liquid as well as part of the fish body undergoing infection due to pathogenic attacks, such as skin and gills. Lysozyme acts in opsonization process that demonstrates the main inflammatory response due to the activation of the complement system and phagocytosis (Sugiani et al., 2012). The lysozyme activity of eggs and offspring also highly increased in the spawning process of vaccinated broodstock compared to egg and offspring produced from unvaccinated broodstock. Lysozyme activity has been found in egg and offspring because basically lysozyme appeared before, briefly, and after hatching to give immunity to fish fingerling (Magnadottir, 2006). Lysozyme activity on offspring from FKC, LPS, and GAB decreased on the tenth day and increased on the fifteenth day along with the offspring age. This was different from the lysozyme activity of offspring from broodstock control vaccine treatment that continued to increase from fifth to the twentieth day. Furthermore, lysozyme activity of fingerling after vaccination on positive control and vaccinated broodstock treatment did not differ significantly. However, FKC and GAB vaccination differed significantly with other treatments. Increased lysozyme activity of eggs and fingerlings was associated with the maternal immunity transfer from broodstock and induced the development of lymphoid organs such as kidneys, thymus, and spleen as increased immune transfer factor derived from broodstock (Swain \& Nayak, 2009).

\section{CONCLUSION}

Vaccination using combined formalin-killed cells (FKC) and lipopolysaccharides (LPS) vaccine of $A$. hydrophila is able to provide induced maternal immunity to the offspring produced. Offspring immunity at the growth beginning was found in the offspring produced from vaccinated broodstock using combined FKC and LPS vaccine. Fingerling vaccination from vaccinated broodstock using combined FKC and LPS vaccine of $A$. hydrophila showed the best RPS value with $57.79 \%$.

\section{REFERENCES}

Aaby P, Kollmann T, Benn CS. 2014. Nonspecifik effects of neonatal and infant vaccination: public-health, immunological and conceptual challenges. Nature Immunology 15: 895-899.

Amrullah, Sukenda, Harris E, Alimuddin, Lusiastuti AM. 2014. Immunogenecity of the $89 \mathrm{kDa}$ toxin protein from extracellular products of streptococcus in Oreochromis niloticus. Journal of Fisheries and Aquatic Science 9: 176-186.

Akbary P, Mirvaghefi AR, Akhlaghi M, Amiri BM, Fereidouni MS. 2015. The effect of letrozole in transfer immunity against lactococcosis to eggs and larvae in rainbow trout Oncorhynchus mykiss, Walbaum. Food and Nutrition Science 6: 254-264.

Barman D, Nen P, Mandal SC, Kumar V. 2013. Aquaculture health management: a new approach. Journal of Marine Science: Research and Development 3: 1-11.

Citarasu T, Alfred Das K, Velmurugsn S, Thanga Viji V, Kumaran T, Michael Babu M. 2011. Isolation of Aeromonas hydrophila from infected oramental fish hatchery during 
massive disease outbreak. International Journal of Current Research 2: 37-41.

Dehghani S, Mostafa A, Dehghani M. 2012. Efficacy of formalin-killed, heat-killed, and lipopolisakaride vaccine against motile aeromonad infection in rainbow trout Oncorhynchus mykiss. Global Veterinaria 9: 409-415.

Fernandez JB, Yambot AV, Almeria O. 2014. Vaccination of Nile tilapia Oreochromis niloticus using lipopolysaccharide (LPS) prepared from Aeromonas hydrophila. International Journal of Fauna and Biological Studies 1: 01-03.

Fu GH, Liu F, Xia JH, Yue GH. 2014. The LBP gene and its association with resistance to Aeromonas hydrophila in tilapia. International Journal Molecular Science 15: 22028-22041.

Hanif A, Bakupoulos V, Leonardos I, Dimitriadis GJ. 2005. The effect of sea bream Sparus aurata broodstock and larva vaccination on the susceptibility by Photobacterium damsela subsp. piscicida and on the humoral immune parameters. Fish and Shellfish Immunology 19: 345-361.

Hardi EH, Pebrianto CB. 2012. Isolation and postulate koch Aeromonas sp. and Pseudomonas sp. on Nile tilapia Oreocrhomis niloticus in Loa Kulu Kutai Kartanegara. Jurnal Ilmu Perikanan Tropis 16: 35-39.

Lacerda IPS, Goncalves YS, de Oliveira STL, Demarqui FN, Krewer CDC, Gouveia GV, Felix WP, Costa MM. 2015. Efficacy of Aeromonas hydrophila S-layer bacterins with different protein profiles as a vaccine in Nile tilapia Oreochromis niloticus. African Journal of Microbiology Research 9: 1770-1777.

Li SW, He H, Zeng RJ, Sheng GP. 2017. Chitin degradation and electricity generation by Aeromonas hydrophila in microbial fuel cells. Chemosphere 168: 293-299.

Magnadottir B. 2006. Inniate immunity of fish: overview. Fish and Shellfish Immunology 20: 137-151.

Magnadottir B. 2010. Immunological control of fish diseases. Marine Biotechnology 12: 361-379.

Mingming H, Fu Hong D, Zhen M, Jilin L. 2014. The effect of vaccinating turbot broodstocks on the maternal immunity transfer to offspring immunity. Fish and Shellfish Immunology 39: 118-124.

Merino S, Canal S, Knirel YA, Tomás JM. 2015. Molecular and chemical analysis of the lipopolysaccharide from Aeromonas hydrophila strain AH-1 (serotype O11). Marine Drugs 13: 2233-2249.

Nisaa K, Sukenda, Junior MZ, Lusiastuti AM, Nuryati S. 2016. Resistance of tilapia Oreochrimis niloticus fry vaccinated at different gonadal developmental stages toward Streptococcus agalactiae infection. Jurnal Veteriner 17: 355-364.

Nisaa K, Sukenda, Junior MZ, Lusiastuti AM, Nuryati S. 2017. Fry tilapia Oreochromis niloticus antibodi improvment against Streptococcus agalactiae trough broodstock vaccination. Pakistan Journal of Biotechnology 14: 9-16.

Rahmaningsih S. 2012. Effect of extract sudawayah with different concentration against Aeromonas hydrophila bacteria for tilapia fish Oreochromis niloticus. Aquasains 1: 1-8.

Reece JB, Urry LA, Cain ML, Wasserman SA, Minorsky PV, Jacson RB. 2014. Campbell Biology. New York (US): Pearson Education.

Sugiani D, Sukenda S, Harris E, Lusiastuti A. M. 2013. Vaccination of tilapia (O. niloticus) using monovalent and bivalent vaccines for motile aeromonas septicemia and streptococcosis disease. Jurnal Riset Akuakultur 8 : 230-239.

Sumiati T, Sukenda, Nuryati S, Lusiastuti A M. 2015. Development of ELISA method to detect specific immune response in Nile tilapia $O$. niloticus vaccinated against $A$. hydrophila and $S$. agalactiae. Jurnal Riset Akuakultur 10: 243-250.

Sukenda, Carman O Carman, Rahman, Hidayatullah D, Yumaidawati NS. 2017. Vaccination in tilapia broodstock with whole cell and disease resistance in its offspring against Aeromonas hydrophila. Jurnal Akuakultur Indonesia 16: 268-276.

Sukenda, Romashona EI, Yuhana M, Pasaribu W, Hidayatullah D. 2018. Efficacy of whole cell and lipopolysaccharide vaccine of Aeromonas hydrophila on juvenil tilapia Oreochromis niloticus against motile aromonad septicemia. ACCL Bioflux 11: 1456-1466

Swain P, Nayak NK. 2009. Role of maternally derived immunity in fish. Fish and Shellfish Immunology 27: 89-99.

Vadstein O, Bergh O, Gatesoupe FJ, GallindoVillaegas J, Mulero V, Picchietti S, Scapigliati G, Makridis P, Olsen Y, Dierckens K, Defoirdt T, Boon N, Schryver PD, Bossier P. 2013. Microbiology and immunology of fish larvae. Review in Aquaculture 5: 1- 25. 
Wang Z, Zhang C. 2010. The role of lysozyme and complement in the antibacterial activity of zebrafish Danio rerio egg cytosol. Fish and Shellfish Immunology 29: 773-77.

Wang SH, Wang Y, Ma J, Ding YC, Zhang SC. 2011. Phosvitin plays a critical role in the immunity of zebrafish embryos via acting as a pattern recognition receptor and an antimicrobial effector. Journal of Biological Chemistry 286: 22653-22664.

Pasaribu W, Sukenda, Nuryati S. 2018. Etje efficacy of Nile tilapia Oreochromis niloticus broodstock and larval immunization against Streptococcus agalactiae and Aeromonas hydrophila. Fishes 3: 1-14.

Zhang S, Wang Z, Wang H. 2013. Review: Maternal immunity in fish. Developmental and Comparative Immunology 39: 72-78.

Zhang ZH, Wu HZ, Xiao OY, Liu Q, Zhang YX. 2014. Booster vaccination with live attenuated Vibrio anguillarum elicits strong protection despite specific antibody response in zebrafish. Journal of Applied Ichthyology 30: 117-120. 